\title{
The Influence of Confucian Culture on Business Management: A Case Study of Chinese Entrepreneurs in Macau
}

\author{
Wang Chunxia \\ Zhejiang University
}

\begin{abstract}
Through thorough interview, questionnaires and observation of 26 Chinese entrepreneurs in Macau, this paper conducts a preliminary empirical analysis of their enterprises. Although Macau has experienced integration of Chinese and Western cultures for centuries, it still retains the traditional Confucian culture. Under its influence, enterprise form of Chinese entrepreneurs in Macau is dominated by family enterprises; enterprises lay more emphasis on merits of loyalty and diligence in their choice of employees; their staff management focuses on the will of the people and interpersonal relationship and at the same time the fine example of managers is also influential. Macau, with a small geographical area, forms a typical "acquaintances society", therefore "relationship" plays an important role in the operation of enterprises and integrity is maintained under the supervision of acquaintances.
\end{abstract}

\section{INTRODUCTION}

In the first half of $20^{\text {th }}$ century, Confucianism was regarded as the barrier to modern economy. German scholar Max Weber (1916) proposed that Confucianism has the lack of unique religious ethics to act as the indispensable initiating power for modern economy. This viewpoint is firmly embraced by scholars such as famous American sociologists Talcott Parsons (1949) and his students, Marion J. Levy (1948) and Robert N. Bellah (1948). For more than half a century Confucianism influenced scholars worldwide.

In the second half of $20^{\text {th }}$ century, East Asia witnessed its economic miracle. Since Confucianism is the common cultural root, academics naturally made the conclusion that Confucianism is beneficial to promoting modern economic development. In doing so, Herman Kahn (1979) put forward the two merits of Confucianism, namely the emphasis on self-restraint, education, solid attitude toward work, family and social responsibility as well as the stress on collectivism and cooperative interpersonal relations. Furthermore, Roderick MacFarquher (1980) pointed out that if western individualism applies to the initial period of industrialization, then Confucius' concept of collectivism can be more applicable to the later period of large-scale industrialization. A last example of promoting Confucianism is Peter Berger (1984) who stressed that in Weber's perception Confucianism is solely a royalty-centric ideology, but that the common Confucianism, at distant from royalty, can act as modern work ethics. Therefore, Jin 
(1995) asserted that Weber's viewpoint that Confucianism hinders the development of capitalism is not justified.

Since the economic reform in later 1970s, mainland China has witnessed huge achievements of economy. This changed the attitude toward traditional Confucius culture. On the one hand, some scholars proposed that economic conception, business-emphasis, business ethics and humanity contained in Confucianism can all be the dynamics for modern market economy development (Ma, 2000). They claimed that the combination of traditional Confucianism and modern entrepreneurship is one of the most significant characteristics of modern Confucius entrepreneurs (e.g. Tang and Luo, 1998; Ming and Xu, 2007; Miao, 2005; Cao, 2008). Furthermore, they advocated the checking power of Confucianism which can counteract the instrumental reasoning function of the modern market economy (Gan, 1989; Zhang, 2002). On the other hand, some scholars affirm that traditional Confucianism contradicts with modern market economy; therefore mainland China should forge a new culture compatible with international criteria (Chen, 2006).

With the rapid development of Chinese family-controlled enterprises worldwide, the study of Confucius family ethics in enterprises has become very popular (e.g. Zhuang, 2007; Wang, 2003; Ma, 2000; You and Ye, 2007; Wang, 2006; Yun and Chen, 2000). These studies showed a positive impact of family ethics upon corporate development. The individual's loyalty to the family is seen as an important motivation for entrepreneurs' efforts. With the support of family, individuals can bear more risks. Furthermore, family enterprises have harmonious internal interpersonal relationship with lower management costs and are more flexible. This enables enterprises to adjust to fast-changing market environments. As such, the interpersonal relationship network can act as the foundation of business trust, thus reducing the unnecessary business conflicts and reducing transaction costs. However, Chinese family enterprises also have obvious drawbacks. For example, only family members can become manager as external managers are not trusted. Furthermore, Chinese enterprises do not pay sufficient attention to corporate systems, which hinders a steady corporate development.

Given the discussion on Chinese family-controlled enterprises the aim of this paper is to study how Confucian culture influences Chinese business entrepreneurs. The objects of study in this paper are Chinese entrepreneurs in Macau. In the studies of overseas Chinese entrepreneurs Macau is generally ignored. This is a pity as in Macau Chinese and Western cultures have been intertwined and influenced each other for centuries. Therefore, this paper probes whether the cultural identity of local Chinese entrepreneurs in Macau has changed and whether their management forms have their own uniqueness in Macau.

Macau, with a total area of 32.8 square kilometers, is located west of Pearl River Delta off the southeast coast of China. The current population of Macau is more than 500 thousand, among which Chinese residents account for $93.8 \%$, Portuguese $1.7 \%$ and Philippines $2 \%$. Macau is a typical immigrant city. Residents of different nationalities, races, places of birth, religions and ancestral homes have formed the characteristics of cultural diversity in Macau (Zhou, 1997). Macau has a special history for several hundreds of years and now is one of China's two Special Administrative Regions (In 1553, Portuguese came to China for trade and obtained the right of abode in Macau. Until 1887, Portugal occupied and forcibly leased Macau, making Macau become the first territory of European countries in East China. On December 20, 1999, Portugal ended administration in Macau and sovereignty of Macau returned to the People's Republic of China (PRC). Under the policy of "one country, two systems", Macau, being a Special 
Administrative Region of PRC, enjoys special legal status. Macau implements the capitalist system and the capitalist way of life while enjoying a high degree of autonomy.

This paper first discusses research methods before turning to the research findings. The paper then focuses on Confucianism in Macau. Findings show four different categories of Chinese family enterprises in Macau. Then, the impacts of Confucianism on Chinese entrepreneurs are described. The impact has been found in different characteristics in intergenerational succession, staff recruitment, family-styled management and business networks.

\section{RESEARCH METHODS AND OBJECTS}

Michael P. Lillis and Robert Guang Tian (2010) suggest that an anthropological approach is the most appropriate way to study cultural factors and assess their impact on an organizational environment. In the same tradition, Zhuang Kongshao and Li Fei discuss the methods, starting points, theoretical targets and study characteristics of anthropological studies to modern business organizations (Zhuang and Li, 2009). Some anthropologists in China also began to research in the field of industry and commerce (Yang and Wang, 2008; Zhou and Sun, 2010).

This research follows traditional anthropological methodologies; the ethnographic method of interview supplemented with questionnaire and (participant) observation. The specific experience of cultural orientation and business management of Chinese entrepreneurs in Macau quoted in the paper is primarily obtained by the author through semi-open interviews in August and September 2009. The author visited 26 Chinese entrepreneurs with average interview time of over one hour and all interviews were recorded. Places of interview were mainly in the office of the respondent, or in restaurants. Some of the interviews were carried out in the hotel lobby and the room where the author stayed.

Interviews are mainly held in Mandarin and Cantonese. The questionnaire gathered basic personal information and basic enterprise information. All questionnaires were completed on the spot except one, which was received by fax after the interview. Since some Chinese entrepreneurs are not willing to expose individual or enterprise information, some of the finallycollected questionnaires are incomplete. In addition, the author conducted field observations through participating in some Chinese entrepreneurs' social occasions, which include art exhibitions held by Chinese entrepreneurs, election dinner and enterprise anniversary, etc.

The collected data is presented as "deep description", that is, "to manifest cultural tradition, values, and norms of conduct, interests, benefits and motivation through meticulous details" (Chen, 2000, p.8). Results are presented in written form and supplemented by charts. But even if statistic data is adopted, it is used to describe social phenomena and not to carry out correlation analysis of data itself.

Chinese entrepreneurs in Macau in this research must meet the following requirements. They must be Macau born Chinese; or Chinese who were not born in Macau but lived in Macau since their youth; or Chinese, who have established an enterprise in Macau for 20 or more years. Furthermore, they must have ten employees or more (including the boss).

Respondent's selection of this research was not by random sampling but the snowball method. The author is acquainted with the respondents through the introduction of Zhejiang University Liaison Office, Macau Peer Scholar, Macau Chamber of Commerce and Macau Foundation staffs and more importantly, the existing respondents were also eager to introduce their entrepreneur friends to accept the author's interview. Due to the diversity of contact intermediary, the composition of our research objects is also very rich, including both successful Chinese 
entrepreneurs of major industries in Macau and many Small and Medium Sized (SME) managers in general industry, whose combination outlines for us a vivid picture of Macau's business culture. Basic personal information of Chinese entrepreneurs in Macau is shown in Table 1.

TABLE 1

BASIC PERSONAL INFORMATION QUESTIONNAIRE STATISTICS

\begin{tabular}{|c|c|c|c|c|c|}
\hline Item & & $\begin{array}{l}\text { Number of } \\
\text { People }\end{array}$ & Item & & $\begin{array}{l}\text { Number of } \\
\text { People }\end{array}$ \\
\hline Age & $\begin{array}{l}\text { Age } \leq 40 \\
\text { Age } 41 \sim 54 \\
\text { Age } \geq 55\end{array}$ & $\begin{array}{l}5 \\
11 \\
10\end{array}$ & Gender & $\begin{array}{l}\text { Male } \\
\text { Female }\end{array}$ & $\begin{array}{l}20 \\
6\end{array}$ \\
\hline $\begin{array}{l}\text { Level of } \\
\text { Education }\end{array}$ & $\begin{array}{l}\text { Middle school } \\
\text { and below } \\
\text { Undergraduate } \\
\text { Master and } \\
\text { above }\end{array}$ & $\begin{array}{l}10 \\
9 \\
7\end{array}$ & Birthplace & $\begin{array}{l}\text { Macau } \\
\text { Mainland } \\
\text { Southeast } \\
\text { Asia }\end{array}$ & $\begin{array}{l}14 \\
11 \\
1\end{array}$ \\
\hline $\begin{array}{l}\text { Education } \\
\text { Types of } \\
\text { Primary } \\
\text { and } \\
\text { Secondary } \\
\text { Schools }\end{array}$ & $\begin{array}{l}\text { Chinese Style } \\
\text { English Style } \\
\text { Portugal Style }\end{array}$ & $\begin{array}{l}20 \\
5 \\
1\end{array}$ & $\begin{array}{l}\text { Religious } \\
\text { Belief }\end{array}$ & $\begin{array}{l}\text { None } \\
\text { Buddhism } \\
\text { Catholic }\end{array}$ & $\begin{array}{l}19 \\
6 \\
1\end{array}$ \\
\hline
\end{tabular}

Chinese people have always occupied an absolutely dominant position in Macau and consequently Chinese culture has formed the mainstream culture. Before 1999, the Portuguese government in Macau implemented a loose colonial rule and did not compel the Chinese to change their cultural traditions. The Portuguese government established government agencies specializing in Chinese affairs, issued the "Code of Chinese Customs" and set up an exclusive court for Chinese people in Macau. The court has a committee consisting of six Chinese to help with the work and to explain to the judge Chinese customs when necessary (Wu, 1995). Under the governance of this binary law, Chinese people in Macau can live and engage in commercial activities according to their own customs. Portuguese rulers more often borrowed the intermediate power of Macanese to govern the Chinese.

The Macanese is a unique resident group in Macau society, including Portuguese descendents living in Macau and hybrid offspring through intermarriage of Portuguese and other ethnic groups in Macau. Characteristics of Macanese are: 1) having Portuguese descent, 2) being Roman Catholic, 3) having a sense of belonging to Portugal, 4) being more proficient in Portuguese than Cantonese, 5) holding a position in Macau government agencies and 6) serving as the medium of Portuguese government ruling Chinese.

Therefore, Macau has experienced more than 400 years of Chinese people getting along with foreigners, but the Chinese has little change in culture. Chinese and Western cultures in Macau have formed the situation of "well water does not mix with river water" and "meeting without being merged" (Song, 2006). At the same time, after becoming a colony, Macau has not been directly shocked by the various political movements China has experienced in the $20^{\text {th }}$ century such as "New Culture Movement", "May Fourth Movement" and "Cultural Revolution". These all contained elements denying traditional Confucian culture in Chinese mainland. In Macau the 
traditional Confucian culture basically has not been interrupted and weaken, but passed on to future generations.

TABLE 2

ENTERPRISE BASIC INFORMATION QUESTIONNAIRE STATISTICS

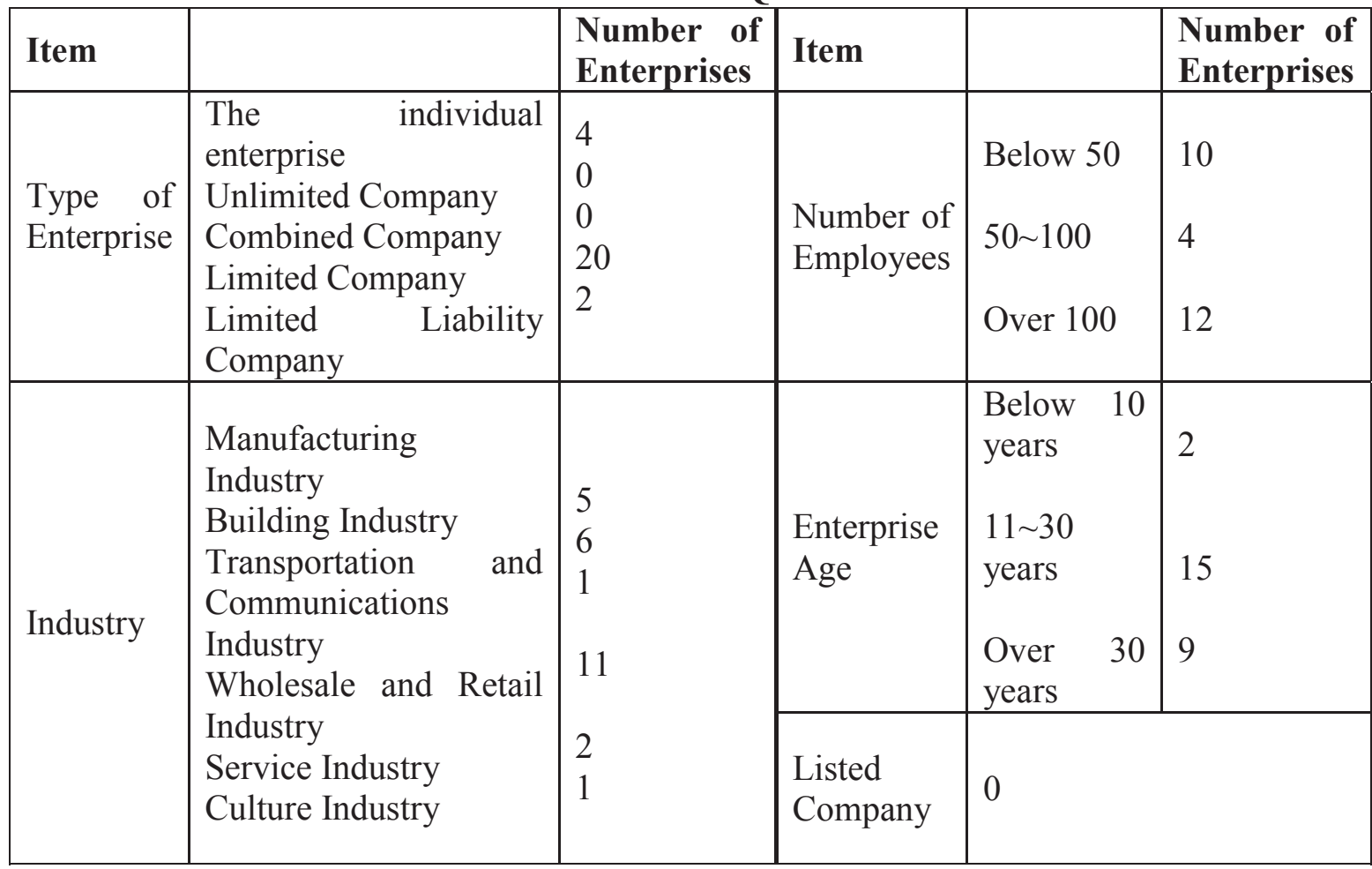

From the Table 1 above, most of the Chinese entrepreneurs in Macau have received Chinese education in primary and secondary schools, and also do not believe in religion, which fully embodies the characteristics of Confucian culture.

Macau is a typical micro-economy; enterprises are mostly small and medium-sized enterprises (SMEs) and have diversified types. Basic information of Chinese entrepreneurs in Macau is shown in Table 2.

\section{TYPES OF CHINESE ENTREPRENEURS' FAMILY ENTREPRISES}

Chinese entrepreneurs' family enterprises are eye-catching either from family enterprises in terms of the viewpoint of ownership or from family operation in terms of the viewpoint of administrative power. The Chinese entrepreneurs we have interviewed are basically family enterprises except for several that are in partnership. 


\section{FIGURE 1 \\ GERSICK MODEL DIAGRAM}

(source: Gersick 1998)

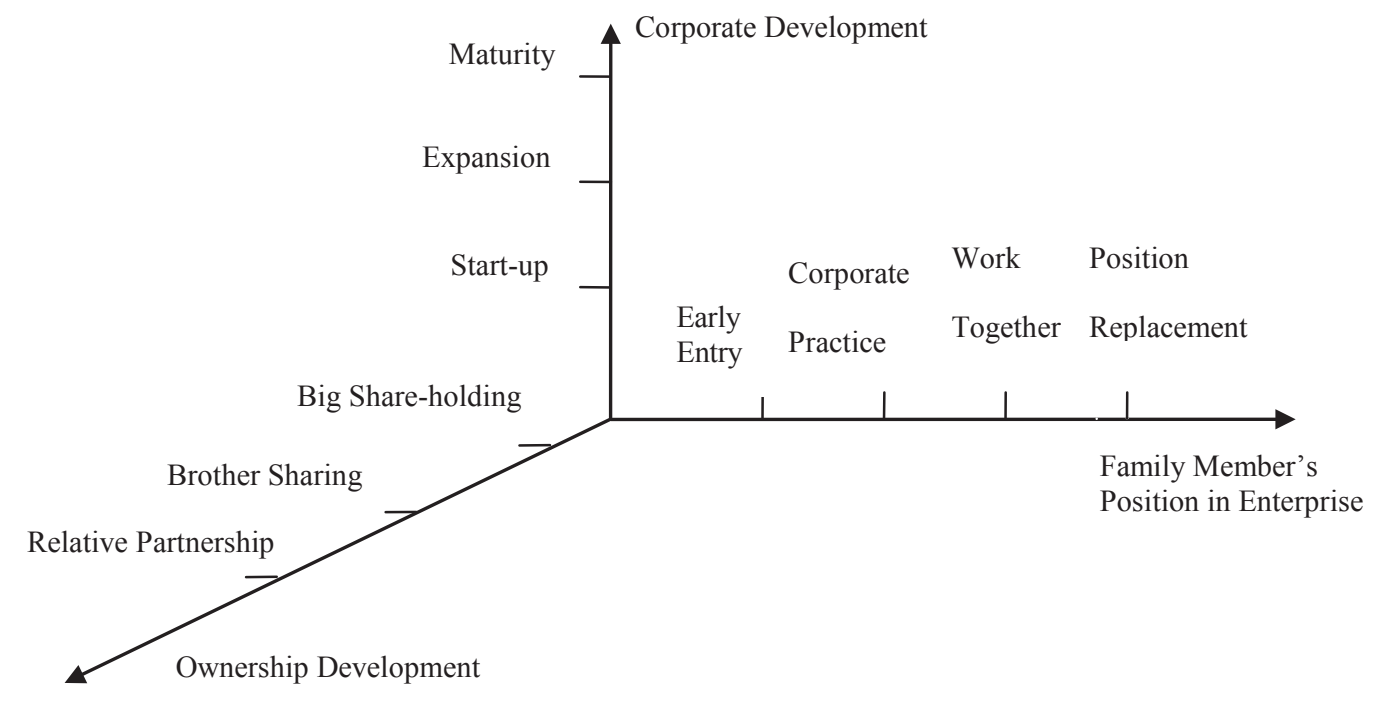

Examining from family enterprise's form and growth changes, economics researcher Chu Xiaoping (2004) has constructed a simple model of family enterprise growth (see Figure 2).

FIGURE 2

GROWTH PROCESS OF FAMILY ENTERPRISES

(source: Chu Xiaoping, 2004)

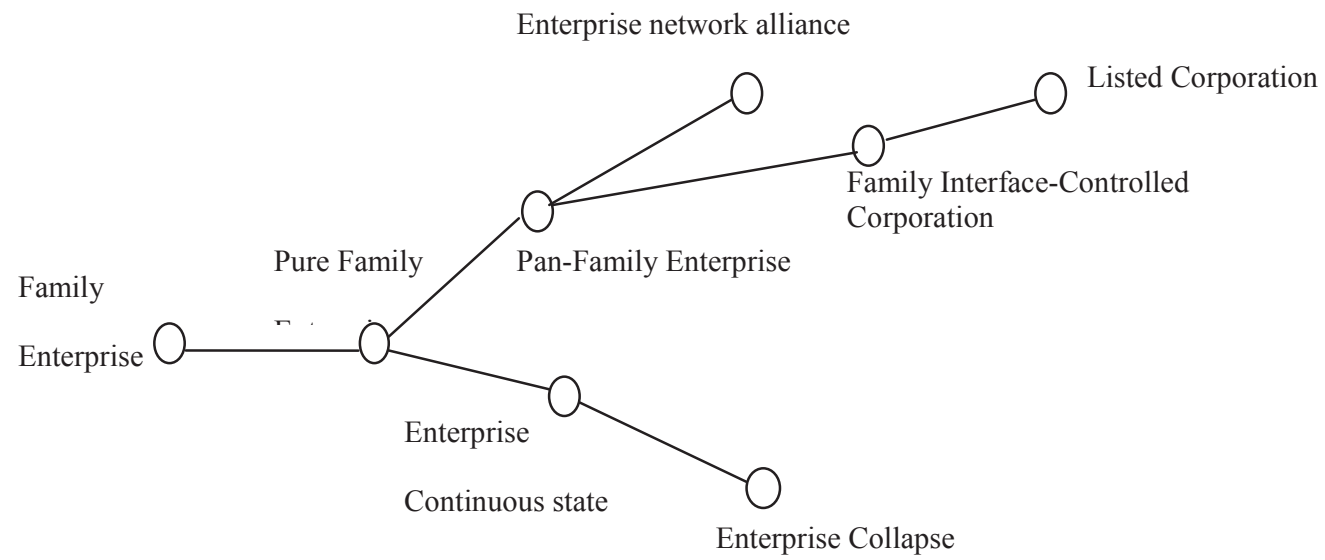


In this paper the two models are combined; resulting in four categories of family enterprises in Macau:

The first category is the core family enterprise. Family is the basic unit of life and production in traditional Chinese society and also an industrial and commercial operation unit. Many small scale enterprises are operated by husbands whose wives are housewives. This is the typical mode of "men going out and women staying at home". Sometimes wives would give opinions, indirectly managing business affairs or the company is run by both husband and wife. For some enterprises, members of the core family will participate in the enterprise together if the father is too busy to attend the business. For example, Mr. Y25 operates a food wholesale and retail trade business. His father, mother and sister are all involved in the business and division of work among family members is very clear. Mr. Y25 said:

"My father mainly supervises and monitors the growth rate of some business and financial management. Finance is the most important part. My mom has worked for more than 20 years in the company and our suppliers and customers of many years are contacted by her. I do more clerical work, such as computer system and retail system. I manage these types of operations more." (Interview with Mr. Y25)

The second category is the pure family enterprise. Due to the small market of Macau, many Chinese entrepreneurs begin to diversify their operation to expand their enterprises, and family members will be invited into the enterprise at this time. Family members pull together driven by common economic interests to cope with the changing external environment of the market. Mr. L18 focuses on transportation industry in Macau and the service industry has been handed over to his married brother to manage. Ms H14 said: "Many of my brothers and sisters are working in my company and we are a family enterprise. There are different divisions of work in finance, production, administration and community service according to different needs of company." Mr. L26 has also used a lot of relatives in hotels invested in mainland China, because "he has more trust in relatives and gives them important posts."

The third category of family enterprises in Macau is the pan-family enterprise. After the scale of enterprise continues to expand, Chinese entrepreneurs in Macau have employed fellow countrymen with geographical relations and schoolmates and the enterprise starts to evolve into pan-family enterprise. In the enterprise of Mr. L24, while his sister holds the position of "executive manager", he also invites his schoolmate to help manage the enterprise and admits that this schoolmate has helped him solve many knotty problems.

The fourth and final category is the group company and enterprise network alliance. None of our respondent in Macau is a listed company. Some family enterprises of Chinese entrepreneurs continue to expand and advance towards "group company" or "enterprise network alliance". This group company consisting of family members on the one hand enables enterprises to diversify and reduce business risk and on the other hand also enables each subsidiary to modernize the enterprise management method. Mr. L17 has four brothers and sisters and they all have their own independent company. There are only several family members in company management and most are recruited talents.

The same is true of Mr. L26's enterprise. As a company founder, Mr. L26 has assets of one billion in Macau and his two sons have grown up. His eldest son is mainly responsible for company's real estate business in Macau while his second son takes care of the hotel business in Beijing, which is basically "all having their own worlds". Mr. W21 also wants to reform his 
company to "enterprise network alliance" after enlargement of his enterprise. But in fact his seven brothers and sisters are in a company and some family members only assume general duties. Mr. W21 considers this is due to the low overall economic development level in Macau.

\section{INTERGENERATIONAL SUCCESSION}

Another important characteristic of family enterprises in Macau, influenced by Confucian culture, is succeeding the father's occupation. In traditional Chinese cultural system, the concept of family continuity is deep-rooted and this continuity not only means the continuity of life, that is, continuity of "species", but also is the continuity of property, official post and honor. Chinese entrepreneurs have accepted the concept of family continuity and they have placed the hope of family's continuous prosperity in the practice of training their children to inherit their own business. Even to this day, there isn't any sign showing that Macau's Chinese pioneering families will hand over their business to professional managers or trust and investment institutions.

Influenced by Western management ideas, some family enterprise leaders explained that ownership and administrative power can be separated in enterprises. However, deep within this is not what they really feel, which is reflected in the following dialog between author (Q.) and Mr. W21 (A.):

Q.: Will you wish your children to inherit your business?

A.: No. He is of a different generation. I will work on finding an external manager more suitable for us.

Q.: What's your greatest hope for your children?

A.: He is only seven years old now. But I do not want him to develop in our industry. I hope he will work in environmental protection industry, because we are able to support him to do these things.

Q.: Still doing business?

A.: Not necessarily. If he is smart enough, he can do research. Labor work or farming (which means the work needing little mental capacity ---- noted by the author) is also ok if he can't do that. That is what I'm saying today, and maybe when I am 50 to 60 years old I will still tell him to come back to work for me. It's really not sure. When I'm unable to get up, I have to call him back to take my business whatever he is engaged in at that time.

In order to make children willing to take over the father's business, Chinese entrepreneurs in Macau consciously develop their sense of family and "filial piety" consciousness. For example, Mr. L17 has lived with his parents and his wife's parents after a successful career. Mr. C10 specially chose Singapore, a place deeply influenced by Confucianism for his daughter to study when she was in high school education. Because of the company's development needs, the son of Mr. L26 and Mr. Y25 were required by their fathers to give up their college degree and return to work in the family's company.

In fact, enterprise inheritance of Chinese entrepreneurs in Macau can be roughly divided into three types. First, the more successful enterprises generally want their children to inherit. The first generation of Chinese entrepreneurs in Macau is not well-educated so they attach great importance to children's education and training for better development of enterprises. Most of 
them send children to prestigious schools in Western countries to learn modern management and business-related expertise (see Table 3). Among the nine successors we have interviewed, five of them have the experience of overseas study and another two acquired their degrees in Hong Kong.

TABLE 3

EDUCATION OF THE SECOND GENERATION OF CHINESE ENTREPRENEURS IN MACAU

\begin{tabular}{|l|l|l|l|l|l|}
\hline $\begin{array}{l}\text { Serial } \\
\text { No. }\end{array}$ & $\begin{array}{l}\text { Alternative } \\
\text { Name }\end{array}$ & $\begin{array}{l}\text { University } \\
\text { Education }\end{array}$ & $\begin{array}{l}\text { Educational } \\
\text { Background }\end{array}$ & Major & Family Industry \\
\hline 1 & Mr. Y25 & Australia & Undergraduate & & Food Wholesale \\
\hline 2 & Mr. L24 & Canada & Undergraduate & Building & Building \\
\hline 3 & Mr. W23 & Canada & Undergraduate & Machinery & Metal Hardware \\
\hline 4 & Mr. L26 & China & Graduate & $\begin{array}{l}\text { International } \\
\text { Politics }\end{array}$ & $\begin{array}{l}\text { Diversified } \\
\text { Conglomerate }\end{array}$ \\
\hline 5 & Mr. H22 & Hong Kong & Graduate & Building & Real Estate \\
\hline 6 & Ms. C12 & $\begin{array}{l}\text { China } \\
\text { and } \\
\text { France }\end{array}$ & $\begin{array}{l}\text { Undergraduate } \\
\text { and Graduate }\end{array}$ & $\begin{array}{l}\text { Design and } \\
\text { Language }\end{array}$ & Textiles \\
\hline 7 & Ms. L15 & U.S.A. & Undergraduate & Economics & $\begin{array}{l}\text { Diversified } \\
\text { Conglomerate }\end{array}$ \\
\hline 8 & Mr. W21 & Macau & Undergraduate & $\begin{array}{l}\text { Management } \\
\text { Science }\end{array}$ & Textiles \\
\hline 9 & Ms. H14 & Hong Kong & Undergraduate & & $\begin{array}{l}\text { Diversified } \\
\text { Conglomerate }\end{array}$ \\
\hline
\end{tabular}

There appear many problems in intergenerational succession of traditional Chinese family enterprise. The traditional Chinese equal distribution of family wealth among children has become a major problem of intergenerational secession. Every child must hold a place in the enterprise. They either divide the company and make the wealth dispersed, or cause the management power dispersed and make the company disaggregated. From enterprise's transition, we often see that the first generation is controlled by one owner; the second generation is operated by brothers and sisters; the third generation is jointly operated by cousins. In this respect, enterprises' intergenerational succession is better in Europe and Japan where the primogeniture is dominant. It not only keeps the wealth and company integrated, but also urges other sons to establish their own businesses.

However, intergenerational succession is not so problematic in Macau. There are five major causes to be found. Firstly, Macau is a typical immigrant city where enterprises are young and most Chinese entrepreneurs are first generation. Secondly, due to the limitation of Macau's objective conditions many enterprises are still SMEs and won't cause too large conflicts of interest. Thirdly, except for several family enterprises of early days, families in Macau nowadays have fewer children. Consequently, fewer sons are born giving more opportunities for daughters to succeed the enterprise. In this study of the nine enterprises which have been succeeded so far, four families are succeeded by their only son, four of them are succeeded by the eldest son, while one is jointly operated by the son and daughter. Fourthly, most small enterprise owners do not advocate their children to inherit their own enterprises, but to make other choices. These small 
enterprise owners are not well-educated and maybe they have no alternative but to do business. Most of them hope that their children can receive higher education and will become various professionals. Mr. L6 told us that his eldest daughter is a teacher and his little daughter is studying in university overseas, hoping to be a professional back in Macau in the future. Mr. Q3 has only one daughter, who is interested in dance and music. Fifthly, Chinese entrepreneurs in Macau will respect their children's wishes. Mr. L7's enterprise is engaged in building design. He said it does not matter whether his children will inherit his own company or not. He just hopes that they develop according to their wishes.

\section{STAFF RECRUITMENT}

\section{Emphasis on Loyalty}

Establishing enterprise culture and team spirit is the common pursuit of Chinese and Western enterprises. But between loyalty and competence, Chinese entrepreneurs in Macau emphasize loyalty when choosing employees. Mr. L18 said: "I'm very choosy about selecting employees. He needn't be smart or too professional, but he must be loyal to the company." Mr. M5 said: "Stability is of prime importance in our choosing employees. I don't mind paying higher salary." Mr. H22 said: "I think loyalty is very important."

There are two ways of screening whether employees are loyal when recruitment; a threemonth trial period and a traditional "fortune telling". In the last mentioned method the employee is selected if the appearance is pleasing to the eye. Mr. L18 and Mr. Q3 said that by looking at the photos on the resume, if they feel "bad", they will not employ them.

Facing the influx of China's mainland labor force, comparatively speaking, Chinese entrepreneurs still favor Macau laborers. Because local people have less mobility and it can more effectively cultivate the staffs' awareness of loyalty. Japanese enterprise employees have the highest loyalty, which is closely related to the lifetime employment. Chinese entrepreneurs in Macau will not easily dismiss workers. Consequently, long lasting enterprises have older employees. The following quotations support the importance of loyalty for Chinese entrepreneurs in Macau:

Ms. G2: "We always employ local people. If an employee is obedient, loyal and has contribution to the company, we will keep him. We will not fire employees as much as possible and no matter how difficult the economy is." (interview with Ms. G2)

Mr. Z4: "Some of my employees have worked in my company for many years and they have grown up with the company and me." (interview with Ms. Z4)

Mr. L26: "The staff around me all have worked more than a decade, and many have worked over ten years or even twenty years. There are many employees over 40 years old in our company." (interview with Ms. Mr. L26)

\section{Emphasis on "Hardworking"}

Macau is a micro economy and is mainly involved in traditional industries. Consequently, required academic qualifications for employees are very low. However, the qualification of whether employees are "working hard" is very important. "Hardworking" means "diligence and endeavor", which emphases a person's quality rather than a quantifiable ability. After Macau's return to China, large numbers of Macau's young people devoted themselves to gambling and to 
earning high salaries. Short term earnings are now the main focus in Macau society. In contrast, the first generation of Chinese entrepreneurs is basically relying on hard work and achieves today's success by accumulation step by step. Therefore, they attach great importance to the factor of "hardworking" when selecting employees:

Ms. G2 said: "In my opinion, everyone has his advantages and disadvantages. Although some people haven't graduated from the primary school, they can also give a hand by working very hard". (interview with Ms. G2)

Mr. H22 believed: "I feel that nowadays many young people maybe affected by some bad information. They think they are smart enough to get a high position in a short time, being a general manager or others. But the process is very important. Many things need to be accumulated and experienced gradually. It's very important to be practical. And the second step is to practice, perform honest work and continue to learn, which are all very important. If you have these traits, you will grasp your opportunity sooner or later. People nowadays don't want to spend time learning and they are too impetuous. (interview with Mr. H22)

Mr. L8: "I see virtue first. In addition, they should work hard, endeavor to do their work and learn. Because he does not know much technology, when coming to the company, he needs to spend more time learning the technologies hard." (interview with Mr. L8)

\section{FAMILY STYLE "HUMANIZED” MANAGEMENT}

The family-style management of Chinese entrepreneurs in Macau is characterized by four different aspects. Firstly, Chinese entrepreneurs in Macau construct a home-like warm atmosphere. Management focus under the influence of Confucian culture is the will of the people and interpersonal relationship, because "the will of the people" is often the most basic condition for long-term stability. Mencius said when a ruler treats happiness of people as his own, people will do likewise; when he treats grief of people as his own, people will do likewise. If he shares joy and sorrow with people in the world, people in the world will definitely join him (Mencius, 1990). This attitude is clearly visible in the interviews with Chinese entrepreneurs in Macau:

Mr. C10 said: "We keep the traditional mode of operation, just like a family. As a family, I should be a so-called elder. I hope my employees well. The company will try to help them, including their personal problems. If staffs borrow money from me, it's ok, but I will ask them about the way it's used. If it is spent in the wrong place, it is totally impossible to lend him the money. And if I find out that the money is used wrongly, I will never allow such things to happen." (interview with Mr. C10)

The enterprise of Mr. L17 has established perfect modern enterprise management system but still attaches great importance to the establishing of family atmosphere within the enterprise. $\mathrm{He}$ stated:

"If an employee has difficulties, we should care about them and let him feel at home. Recently one of my managers in production department has a traffic 
accident, a traffic collision. Some enterprises wanted to hire him away with high salary some time earlier and he was in hesitation. I believe that if he is hesitant then we need to discuss. So I talked with him in personal, because a talented person wants to feel that the boss thinks highly of him and listens to his views. After he was sent to hospital due to the serious traffic accident, my company gave him full medical treatment and welfare and I also continued to send management including my wife to visit him in the hospital. He was very moved and even the hospital staff was moved. This is one way of our employing people "We treat every employee of the company as a family and influence and transform him through words and action. If you do so, the entire company has the feeling of belonging." (interview with Mr. L17)

Other Chinese entrepreneurs too emphasized the importance of a family atmosphere:

Mr. G2: "I care for every staff and I will go to help them if they have too many things to do at home which gives them a feeling that working in my company is comfortable. They will work hard every day without supervision. Therefore, I will protect him so long as he is my employee." (interview with Mr. L17)

Mr. Q3: "The enterprises we have established in Macau are relatively small and have a few employees, only a few dozens, so I adopt humanized management. I often communicate with my staff directly, including the lowest-level employees." (interview with Mr. L17)

Mr. Z11: "My employees have followed me many years since I started my business. If I don't have social engagements after work, I would like to talk with my staffs. We will have fun on Sunday, such as fishing, BBQ or swimming. It's wonderful." (interview with Mr. L17)

Secondly, to establish a family-style management Chinese entrepreneurs should trust your subordinates and give them a free hand.

Mr. L26 said: "I almost never manage the little things like arriving late or leaving early. As long as you get things done, it's ok." (interview with Mr. L26)

Mr. C10 said: "Because employees are the foundation for the development of the company, the company needs to understand their needs, give them a free hand to do things as much as possible and trust them." (interview with Mr. C10)

Thirdly, when employees make mistakes, managers are always tolerant in order to take care of the employees' "face". The respondents:

Mr. Y9 said: "I don't always abuse others and also don't like to treat my subordinates with a tough attitude. I like to reason with them or discuss how to learn with them. I even criticize them in the form of encouragement." (interview with Mr. Y9)

Ms. C12 said: "You should be strict with your subordinates, but the most important thing is to tolerate. You can criticize them and you can be demanding if 
they make mistakes, but you must be tolerant. You can criticize him but you should teach him and then forgive him." (interview with Ms. C12)

Mr. Q3 said: "Everyone makes mistakes but we should make it clear whether it is a blunder or small error and whether it is made on purpose or not. The mistake has many aspects and if he can correct the mistakes, I hope he can gain experience from it." (interview with Mr. Q3)

Fourthly, in the context of Confucian culture, self-cultivation is the essential training for managers and is also the key to management success. It's said in The Analects of Confucius that if the ruler himself is upright all will go well even though he does not give orders; but if he himself is not upright, even though he gives orders, they will not be obeyed, which means that leaders should strengthen self-cultivation and set a good example so as to constrain subordinates (Confucius, 2007). Popular understanding is that if you want to do management well, you must solve the problem of behaving yourself first and that example is more important than precept.

Mr. C10 told: "As a boss, first of all, you should be strict with yourself. I start work very early everyday and set a good example for employees, thus virtually becoming their model. I usually ask employees to do more exercise and provide good conditions for them, i.e. our company has a basketball court. Such actions will virtually bring some positive information to them and they will also pass them on after work." (interview with Mr. C10)

\section{BUSINESS OPERATION IN MACAU'S “ACQUINTANCES SOCIETY”}

\section{"Relationship" and Business}

Macau is small and densely populated and interaction between people is of high frequency. Chinese immigrants have set up numerous associations of fellow provincials or townsmen and clansmen associations to strengthen the links. In order to fight against the rule of Portugal, various types of associations have been set up to protect their own rights. Macau, after returning to Chinese sovereignty, has a high degree of political autonomy with an increasing number of civil societies. The total number of associations has reached 4,000 giving Macau the highest density of associations in the world. Therefore, Macau Chinese community is in fact an "acquaintances society" under the influence of traditional Confucian culture. One of the respondents described such situation to us;

"Macau is very small and people are not so many. Basically he knows you and you know him. Many people are your classmates, your neighbors, your acquaintances and your friends. So in Macau contact with a person is not a single relationship. It is quite common. Macau society is more harmonious due to closer interpersonal relationship, which is different from other places. Macau has similar characteristics with some small towns, that is, closer interpersonal relationship and no quarrels and fights, for people are probably friends of our friends." (interview with respondent)

In the "acquaintances society", "relationships" are important. In order to create more business opportunities for their own companies, Chinese entrepreneurs in Macau attach great importance 
to establish and expand their "relationship circles". To establish a relationship one has to inherit the existing relationship of father and than to make the personal "relationship circle" be shared in a broader range through introduction of relatives and friends. Finally, through one should participate in or establish or various communities to know more people and build more "relationships".

There is no doubt that the above mentioned "relationship" category includes governmentbusiness relationships. In Macau, strong Chinese entrepreneurs will establish "relationships" with government officials and try to curry favor to figures of strength in government agencies through huge bribes. Macau implements the market economic system, but land and human resources are not regulated by market and are mainly deployed through the "visible hand" of government (Lou, 2009). Therefore, corruption of Macau occurs mainly in the fields of land lease and government engineering projects. In 2008, Ou Wan-long, the former secretary for transport and public works, was sentenced to 27 years of imprisonment for accepting bribes of 804 million Yuan (about $\$ 120$ million USD) during his tenure. The corruption caused by improper business-government relationship in Macau has also aroused widespread discontent in the society.

\section{Acquaintances and Integrity}

Confucius emphasizes the importance of integrity fully and said that only when a man keeps his word he can get other people's recognition (Confucius, 2007). In Macau, to business integrity is honored by "public praise" a traditional system which passes reputation from mouth to mouth. It is believed that public praise brings in more business. For example, the print shop of Mr. Z4 does not have any salesmen while customers come because of his reputation. The drugstore of Ms. G2 also sells authentic medicine with good efficacy and Chinese mainland tourists are satisfied after purchasing real authentic medicines. Since the mainland has a lot of fake drugs tourist regularly return to the store. In a final example, Mr. L8 deals with lift and escalator marketing and he also believes that doing business must be credible, because credibility is the best way to do long-term business.

If we honor integrity for the "public praise" of business, which is the external material interest stimulus, then our honoring integrity because of conscious constrains at heart has a strong sense of morality. Integrity itself is a moral requirement, or a value. Chinese entrepreneurs in Macau use constraints at heart to explain the reason why they honor "integrity":

Mr. Q3 thinks: "Doing business must be credible and we should have the spirit of service for guests, which is the most important. We must try our best and we can't work in a slipshod manner. We must first pass our own test and then show the product to others. This is the most important thing." (interview with Mr. Q3)

Mr. C10 said: "The business done by my company has been appreciated by customers. We should try our best, have a clear conscience and be responsible to others and to ourselves. These are affected values are passed on by the elder generation." (interview with Mr. C10)

Most of the residents in Macau are migrants from Guangdong Province of China and Ms. L20 held that most of them have retained the traditional values. "Teeth can be used as gold", as the local folk proverb in Guangdong, means that we must keep our word. These Guangdong migrants generally did not sign a contract when doing business in the past. If there was a dispute, 
they would invite respected persons in the community to mediate. Influenced by contract awareness, now most Chinese entrepreneurs in Macau have gradually established a legal sense. When there is a contract dispute, they will go to court for resolution. However, even if a commercial contract is signed, Chinese entrepreneurs can still put the traditional integrity and ethics into the contract, thus avoiding contract frauds. Mr. L8 said

"We are conscientious when handling our industry and many items are clearly listed in biding document. This is not just credibility issue but also an issue of conscience. When you do something, it's ok if you pass your own test." (interview with Mr. L8)

\section{CONCLUSION}

Macau has experienced hundreds of years of interchanging of Chinese and Western cultures, but up to now it still retains the profound Confucian culture. This paper explores how Confucian culture influences Chinese business entrepreneurs and the reasons why Confucianism still exists in Macau. Firstly, Portuguese government poses loose colonist governance, not forcing Chinese people to change their cultural traditions. Besides, Confucius culture is not influenced by mainland Chinese politics. A series of political and cultural movements that negates traditional culture values have not impacted Macau. But, this analysis only involves the external factors for the existence of Confucianism in Macau, without probing the internal factors. The reason why Confucius culture still exists in Macau is closely related to the transmission instrument of Confucius culture. Chinese immigrants tend to cluster. Therefore, in Macau Chinese people are organized in associations which are based upon birthplace, trade and interest. In Macau, there are 4000 societies, which make Macau the most intensive area of associates in the world. These often have apparent traditional characteristics, which also exert important impacts on the social integration and cultural confirmation.

Since Macau belongs to typical micro economy, many enterprises are small and mediumsized ones and they have been established for a short time, so enterprise form is dominated by family enterprise. The first generation of entrepreneurs influenced deeply by the traditional culture, reflected more a tradition based on Confucian culture in management, emphasizing morality and tender feelings. Enterprises emphasize family members, especially the eldest son's taking over of the enterprise. Enterprises pay more attention to the merits of loyalty and diligence in the choice of staffs. The focus of staff management is the will of the people, while good example of managers is also stressed. The characteristic of Macau's "acquaintance society" enables "relationship" to play an important role in enterprise operation, and integrity is also maintained under the supervision of acquaintances. All these make this island city Macau where Chinese and foreigners have lived together here for over four hundred of years still keep its rich flavor of traditional culture.

Whether Confucius culture is beneficial to or hindering the market economy is difficult to judge in this paper. But the cultural consciousness and cultural acceptance embodied by Macau entrepreneurs in the interviews demonstrates the complication and value of the paper. Enterprises are both the "economic person" and "social person". Our research is not limited only to the impacts of Confucius culture on economic development. It also extends to the impacts of Confucius culture upon Chinese entrepreneurs' value, family relation, political conception and social responsibility. 
However, after the return of Macau to the PRC, due to the wide introduction of gambling into Macau from the US, the gambling industry has dominated. Meanwhile, the western corporate operation modes of gambling also bring new experience of corporate management to Macau. The 2nd-generation owners of Macau's Chinese enterprises mostly have received western education, which may bring new changes in future management. We also sense the transformation from traditional society to modernity through the interviews.

\section{ENDNOTE}

This paper is the initial phase achievement of "Research on Traditional Confucian Values and Behaviors of Chinese Entrepreneurs in Macau" project, which is hosted by Zhou Shengchun, director of Confucius Entrepreneurs and East Asia Research Center and sponsored by Macau Fund. The author sincerely thanks Kong Xianglai, Chen Qianqian, Zeng Junrong, Pei Zhijun and Yue Junyi for their contribution to the data collection and the initial fieldwork.

\section{REFERENCES}

Confucius (2007). The Analects. Beijing: Zhong Hua Books Company.

Cao Jun (2008). Confucius Entrepreneur Cultivation: Modern Principles of Confucius Organization Behaviors. Beijing: Oriental Press.

Chen Zhiwu (2006). The Difficulties Encountered by Chinese Confucius Entrepreneurs. Chinese Entrepreneurs, 2006 (23): 40-42.

Chen Xiangming (2000). Research Method of Qualitative and Social Science Research. Beijing: Education Science Press.

Chu Xiaoping (2004). Growth of Family Enterprises and the Integration of Social Capital.

Beijing: Economic Science Press.

Gan Yang (1989). We are Creating Tradition. Taipei: Lian-Jing Publishing Co.

Gersick, Kelin E. (1998). Generation to Generation: Life Cycles of the Family Business. Beijing: Economic Daily Press.

Herman Kahn (1979). World Economic Development: 1979 and Beyond. London: Croom Helm.

Ji Douyong (2001). Confucius Entrepreneurs Spirit. Beijing: Economic Daily Press.

Jin Yaoji (1989). Weber's Theory Re-exploration, Confucius Ethics and Economic Development. Harbin: Heilongjiang Education Press.

Lou Shenghua (2009). New Order: Research on Macau Social Governance. Beijing: Social Sciences Academic Press. 
Lillis, Michael P. and Robert Guang Tian (2010). Cultural Issues in the Business World: An Anthropological Perspective. Journal of Social Sciences, 6(1): 99-112.

Ma Tao (2000). The Confucian tradition and the modern market economy, Shanghai: Fudan University Press.

Marion J. Levy (1948). The Family Revolution in Modern China. Cambridge: Harvard University Press.

Max Weber (1964). The Religion of China: Confucianism and Taoism. New York: The Free Press.

Mencius (1990). Mencius. Shanghai: Shanghai ancient books press.

Miao Zehua (2005). the Confucius Economic Ethics and Value Orientation of New Confucius Entrepreneurs. Modern Economic Management, 27 (5): 56-59.

Mingxu and Xu Mengna (2007). Confucius Entrepreneurs and East Asia Civilization. Zhejiang University Journal,37(1): 5-15.

Peter Berger (1984). Secularity-West and East. Chinese Forum, 19 (6): 14-18.

Robert N. Bellah (1948). Tokugawa Religion. Glencoe: The Free Press.

Roderick MacFarquher (1980). The Post-Confucian Challenge. The Economist, Feb, (9): 67-72.

Song Bonian (2006). Macau Cultural Interviews. Macau: Macau Polytechnic Institute.

Talcott Parsons (1949). The Structure of Social Action. New York: The Free Press.

Tang Kailin, and Luo Nengsheng (1998), Combination and Promotion-the Forging of Traditional Confucius Entrepreneurs Spirit and Modern Market Rationale. Changsha: Hunan People's Press.

Wang Ping (2003). The Ethnicity Thinking and Private Enterprise Management in China. Hong Kong: China's Culture Comments Co., LTD.

Wang Qiulan (2006). Analysis on the System of Family Business in East Asia. Beijing: Economy \& Science Press.

Wu Zhiliang (1995). Political System in Macau. Macau: Macau Foundation Publishing.

Yang Shengmin and Wang Hansheng (2008). An Investigation on the Xinjiang village in Beijing. Northwest Ethno-National Studies, 57 (2): 1-9. 
You Minghan and Ye Chunsheng (2007). Native Chinese Management Research. Guangzhou: Huanan Technology University Press.

Yun Guanping and Chen Qiaozhi (2000). Research on Southeast Asian Chinese Enterprise Management. Beijing: Economic Management Press.

Zhuang Kongshao and Li Fei (2008). Anthropological Studies to the Modern Organizations and Their Cultures. Ethno-National Studies, 2008 (3): 51-60.

Zhang Desheng (2002). Confucianism Merchants and Modern Society: the Relation between Profits and Justice. Nanjing: Nanjing University Press.

Zhou Daming (1997). Ethnic Groups in Macau. Social Sciences in China, 107 (5): 142-155.

Zhou Daming and Sun Xiaoyun (2010). Group Differences among Nongmingong: A Follow-up Ethnographic Case Study. International Journal of Business Anthropology, Vol. 1 (1):79-94.

Zhuang Peizhang (2007). Institutional Change of Chinese Family Business, Beijing: Social Science literature Press. 